\title{
DOES INDIVIDUAL ATTRIBUTES MATTERS ON THE EMPLOYABILITY READINESS AMONG ENGINEERING GRADUATES IN THE HIGH EDUCATION INSTITUTES IN OMAN
}

\author{
Masoud Rashid Al Hinai \\ PhD Research Fellow \\ Faculty of Business and Accountancy \\ University of Selangor \\ 40000 Shah Alam, Selangor Darul Ehsan, Malaysia \\ E-mail: alhinai6602@gmail.com \\ Dr. Abul Bashar Bhuiyan \\ Associate Professor \\ Faculty of Business and Accountancy \\ University of Selangor \\ 40000 Shah Alam, Selangor Darul Ehsan, Malaysia \\ E-mail: bashariuk@gmail.com \\ Dr. Nor Azilah Husin \\ Associate Professor \& Deputy Dean \\ Faculty of Business and Accountancy \\ University of Selangor \\ 40000 Shah Alam, Selangor Darul Ehsan, Malaysia \\ E-mail: nor_azilah@unisel.edu.my
}

Received: October 03, 2021 Accepted: October 30, 2021 Online Published: November 25, 2021

DOI: $10.46545 /$ aijbms.v3i1.223

URL: https://doi.org/10.46545/aijbms.v3i1.223

\begin{abstract}
The aim of this study is to examine the effects individual attributes on the Employability Readiness among engineering graduates of the High Education Institutes in Oman. The study adopted selfdirected structured questionnaire which was distributed to a sample of engineering students and graduates from a number of colleges and universities. The study used the structural equation modelling (SEM) for analysing the collected data. The findings of the statistical analysis of the study showed the most influential individual attributes on graduates' readiness for employability are workshop attendance that affect the attainment of the technical skills of the graduates, family motivations, and graduates' career orientations that help graduates to identify future career requirements and future career opportunities, and graduates' personal learning targets. Also, class attendance, academic excellence, financial sources, and parents' career position showed
\end{abstract}


high important effects as well. The findings of this attribute which consist of the individual attributes of personnel's' values, attitudes, abilities, and work-life balance enhance the graduates attainment of the adaptability and flexibility attributes for their future readiness for employability. Therefore, study findings showed Individual attributes factor has high influence on the Readiness for Employability of the graduates in Oman. Finally, the study's implementations and recommendations could be transferred to the Gulf and Arab or other countries' contexts having similar settings of HE systems and similar issues of skills gap and employability concern of their graduates.

Keywords: Individual Attributes, Employability Readiness, Engineering Graduates, High Education Institutes, Oman

\section{INTRODUCTION}

One of the essential objective of the Higher Education (HE) system in Oman is enhancing the skills and qualities of the fresh graduates to meet the requirement of the labor market, however, most graduates still lack the acquirement of the required Readiness for Employability skills (Al Hinai, Bhuiyan, \& Husin, 2020a, 2020b, 2020c; Lim, Lee, Yap, \& Ling, 2016; Rahman \& Bhuiyan, 2019; Yang, Cheung, \& Fang, 2015).

Many kinds of studies found that graduates of the HEIs in Oman and regional countries face strong challenges to get easily employed because those graduates seriously lack the employability skills (AlMunajjed, Sabbagh, \& Insight, 2011). As a result of the Skills Gap of the $\mathrm{HE}$ graduates, the unemployment rate among the Omani graduates is high as another research concluded that many Omani youth graduates spend more than three years to find a job (NCSI, 2015). A recent study on the desired Readiness for Employability skills required for Omani Engineers listed thirteen essential skills including Analytical thinking or critical thinking, Problem solving skills (The ability to analyze facts and situations), Creative thinking (The ability to develop and apply appropriate solutions), Communication skills including listening and questioning, Capacity for lifelong learning including readiness to contribute to new ideas, Capacity for lifelong learning including openness to new ideas, Teamwork including respecting others, cooperating, negotiating / persuading, and contributing to discussions, Professional ethics and morality, Entrepreneurial skills, Leadership skills, Proficiency in written and oral English, Specialization and industrial required technical skills, Capacity for applying knowledge in practice (Al Hinai et al., 2020a). Also, in an important study of graduates attributes factors affecting the Engineers graduates' attainment of the required Readiness for Employability skills, five attributes factors were believed to have the most influential matters on the acquirement of required employability skills including Human capital attributes, Social capital attributes, Individual attributes, Institution-Related attributes, and Active learning attributes (Al Hinai et al., 2020b).

Therefore, this study aims to determine the effect of Individual attributes factors on the graduates' readiness for employability to improve the quality of engineering education which consequently, will enable the engineering colleges to produce graduates suitable for employment. More specifically, this study aims to answer the following question.

\section{LITERATURE REVIEW}

The aspect of individual attributes has recognised as an essential part of a career success (Fugate \& Ashforth, 2003). For any graduates having adaptability and flexibility attributes help the graduate to deal with any required change and also make the graduate ready to deal with future 
career changes and therefore he can enhance his job desired outcomes (Fugate, Kinicki, \& Ashforth, 2004; Heijde \& Van Der Heijden, 2006). Bridgstock (2009) in his paper "The graduate attributes we've overlooked: Enhancing graduate employability through career management skills", splits career skills into as "self-management skills and career building skills". The selfmanagement skills consist of the individual attributes of personnel's' "values, attitudes, abilities, aptitudes, interests and work-life balance". While career building skills help graduates to sail and progress in their careers (Bridgstock, 2009). Therefore, graduates are desired to attain the adaptability and flexibility attributes for their future readiness for employability.

In a study of the effect of the individual and personnel attributes of the graduates and their effect on employability, productive self-management skills (organisation, planning, and selfdiscipline), creative and innovative skills (work independently, entrepreneurship, self-motivated, and innovative thinking), new technology adaptation skills (information computer technology skills and use of modern tools, equipment and technologies), personal attributes and individual differences (ethical conduct, positive attitude, and responsibility), lifelong learning skills, leadership skills, and finally global citizenship skills (Knowledge of another Language and awareness of global issues) were found essential for graduates Readiness for Employability (Sarfraz, Rajendran, Hewege, \& Mohan, 2018).

Also, in an analysis study of the influencing factors of job attainment. The study findings indicated that work place decision preferences widely in line with the common believe of the contents of graduates' attributes factors, consisting of work technical experience, attainment of required industrial generic skills and abilities, and finally the outstanding integrity of the graduate which is an important individual attributes affecting skills and career attainmen (Jackson, 2014). Besides, "integrity, reliability and teamwork" which are graduates individual attributes were found as the most essential generic skills connected to employability of graduates (Gupta, Singh, \& Kaushik, 2018). In addition, another study found that students lack the understanding of the sets of the employability skills of the fourth industrial revolution as a strong indication of gap of employability skills provided by the HEIs and the labour market demands which affect individual graduates getting employability (Pauceanu, Rabie, \& Moustafa, 2020).

Additionally, the importance of individuals classroom attendance, training induction learning, and evaluation activities in the WIL episode were recognised essential for the development of the required employability skills and recognition of elements which hinder ability accumulation and achievement. Besides, work induced training programmes as well as course size, format and layout found to be important as well (Jackson, 2015). Also, a new approach to employability was considered by developing a framework that incorporates six key dimensions which included human capital, social capital, individual attributes, individual behaviours, perceived employability, and labour market factors. The study was based on UK and Australian data. The study model contributed to the understanding of the individual, institutional and contextual variables that impact employability and career results among graduates. Moreover, the model also identified zones of individual obligation (for students and graduates) (Clarke, 2018).

Others emphasis essentially at self-perception for graduates employment success. They have different definition for employability to be based in the individual's perception of the possibility of getting and sustaining employment. Thus individual perception of employability is connected to what the graduate himself do to attain competencies including his abilities, capacities and skills along with his behavioural attitude towards employment and future career (Vanhercke, De Cuyper, Peeters, \& De Witte, 2014). Also, students' manner of speaking, their mental alertness, and their ability for presenting ideas found to be dominated in a study of identifying the Most 
Predictive Attributes among Employability Signals of undergraduate Students . While, the other attributes such as the physical conditions of the graduates, their self-confidence, their communication skills abilities, the students' performance rating, and the graduates' general appearance scored as stated respectively (Casuat \& Festijo, 2020).

Therefore, the individual attributes elements intended to be analysed in this study are Personal planning, Career Orientations, Class attendance, Family motivation, Parents career position, Academic excellence, and Financial sources of study (Al Hinai et al., 2020b).

Finally, the initial theoretical framework representing the relationship among the study variables is presented in figure 1 . This portion of the framework is obtained from a wider study of factors affecting the Readiness for employability among Engineering graduates of the HEIs in Oman (Al Hinai et al., 2020b).

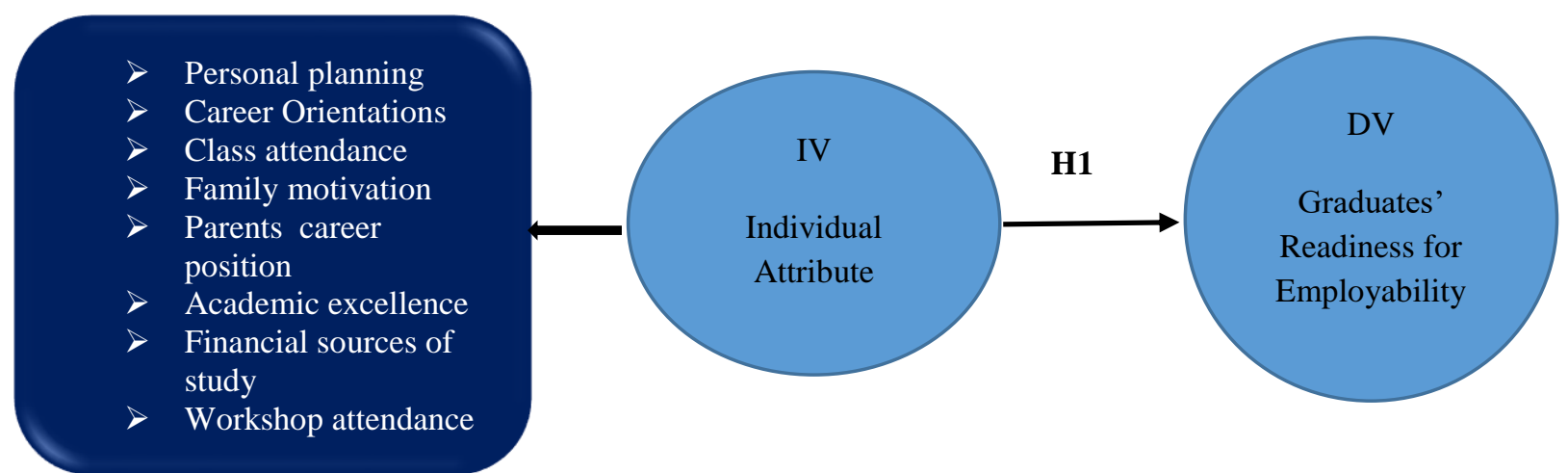

Figure 1. The influence of Individual Attributes on Graduates' Readiness for Employability among Engineering graduates of the HEIs in Oman

\section{$H_{1}:$ There is a significant relationship between Individual attributes and graduate's readiness for employability among engineering graduates of the HEIs in Oman.}

\section{METHODOLOGY}

The simple random characteristic strategy of the sampling technique was utilised by collecting data from an intended sample consisting from 340 random sample of engineering students obtained from different HEIs in Oman. To ensure the validity and clarity of the questionnaires, a panel of experts were consulted consisting of two academic engineering experts and two language experts. The findings of this study are accomplished utilizing the quantitative statistical methodology approach. This approach implements a numerical analysis using survey questionnaires as the base to collect data from students, and graduates (Creswell \& Creswell, 2017; Dörnyei, 2007)..

Human Capital Theory were utilised as the underpinning theory of the study since it examines the financial benefits resulting from the investments in people' skills and resources. Such investment will result to have highly-skilled labors placed in highly-skilled careers, which could improve the nation's economy and prosperity (Becker, 1962; Leslie \& Brinkman, 1988; McMahon, 2009; Schultz, 1963; Slaughter, Taylor, \& Rosinger, 2015). Also, two statistical programs are used for data analysis. The first one is the use of the Statistical Package for the Social Studies (SPSS) version 26.0 to administer the preliminary data analysis. The second statistical program utilised for this study was the Partial Least Square Structural Equation Modelling (PLSSEM) software. This program is used for the evaluation of the reflective measurement model, 
structural model, path analysis, and hypotheses testing (Hair Jr, Sarstedt, Ringle, \& Gudergan, 2017).

\section{DISCUSSION OF RESEARCH QUESTIONS AND FINDINGS}

\section{Testing for Normality}

The descriptive statistics present the statistical distribution of the study data that includes the observed variables, the means, standard deviations, skewness, and kurtosis. The SPSS 26 version software was used to provide the descriptive statistics which highlights the statistical distribution of the collected data of the sampled pilot test. This statistical data represents the study assigned variables, the means and the standard deviations. In addition, skewness, and kurtosis are employed for testing the normality of the data. Table 1 show the results of the descriptive statistics calculation and testing the normality of the data. As shown in the tables, all selected variables have skewness values as well as kurtosis values within the range -3 and +3 which signify that the study variables are normally distributed. Specifically, the recommended values for skewness are between 3 and + 3 , and the values for kurtosis are between -10 to +10 when using SEM (Urbano, 2013).

Table 1. The skewness and kurtosis for normality

\begin{tabular}{ccccccc}
\hline & \multicolumn{5}{c}{$\begin{array}{c}\text { Descriptive Statistics } \\
\text { Skewness }\end{array}$} & \multicolumn{2}{c}{ Kurtosis } & \\
& & \multicolumn{2}{c}{} & & & Normality \\
& Statistic & Statistic & Std. Error & Statistic & Std. Error & assumption \\
\hline IA1 & 340 & -.999 & .132 & .977 & .264 & Normal \\
IA2 & 340 & -1.145 & .132 & 1.486 & .264 & Normal \\
IA3 & 340 & -1.028 & .132 & .905 & .264 & Normal \\
IA4 & 340 & -1.174 & .132 & 1.568 & .264 & Normal \\
IA5 & 340 & -.755 & .132 & .220 & .264 & Normal \\
IA6 & 340 & -1.273 & .132 & 1.511 & .264 & Normal \\
IA7 & 340 & -1.122 & .132 & 1.015 & .264 & Normal \\
IA8 & 340 & -.706 & .132 & -.367 & .264 & Normal \\
IA9 & 340 & -.971 & .132 & .568 & .264 & Normal \\
IA10 & 340 & -.549 & .132 & -.087 & .264 & Normal \\
\hline
\end{tabular}

Table 2. Mean and standard deviation-Individual Attributes

\section{Descriptive Statistics-Individual Attributes}

Item

workshop attendance of graduates enhances their attainment of readiness of employability skills

family motivations elevate graduates' attainment of readiness of employability skills

graduates with clear career orientations can easily identify future career requirements graduates who plan to achieve their learning goal(s) are more ready for employment
Std.

N Mean Deviation

$\begin{array}{lll}340 & 5.8382 & 1.33271\end{array}$

$\begin{array}{lll}340 & 5.7588 & 1.32619\end{array}$

$340 \quad 5.6206 \quad 1.22421$

$\begin{array}{lll}340 & 5.5441 & 1.27413\end{array}$ 


\begin{tabular}{lccc}
\hline $\begin{array}{l}\text { graduates with clear career orientations can easily identify future } \\
\text { career opportunities }\end{array}$ & 340 & 5.5353 & 1.33102 \\
$\begin{array}{l}\text { graduates who set their personal learning targets are more ready for } \\
\text { employment }\end{array}$ & 340 & 5.4912 & 1.34469 \\
$\begin{array}{l}\text { academic excellence of graduates can enlarge the chances of their } \\
\text { future readiness for employability } \\
\text { class attendance of graduates reinforces the attainment of readiness } \\
\text { of employability skills } \\
\text { financial sources of study affect graduates' attainment of readiness of }\end{array}$ & 340 & 5.4529 & 1.47171 \\
$\begin{array}{l}\text { employability skills } \\
\text { parents' career positions magnify students' future readiness for }\end{array}$ & 340.9147 & 1.56899 \\
$\begin{array}{l}\text { employability } \\
\text { Individual Attributes Average score }\end{array}$ & 340 & 5.4747 & 1.72311 \\
\hline
\end{tabular}

Note: using Seven-Dimensional Likert scale (1represents "Strongly disagree", and 7 represents "Strongly agree")

Using SPSS version 26, table 2 indicates that the most influential individual attributes on graduates' readiness for employability are workshop attendance that affect the attainment of the technical skills of the graduates (Jackson, 2015), family motivations, graduates' career orientations that help graduates to identify future career requirements and future career opportunities (Clarke, 2018), and graduates' personal learning targets (Craps et al., 2017). While, class attendance, academic excellence, financial sources, and parents' career position have lesser effects. The findings of this attribute which consist of the individual attributes of personnel's' "values, attitudes, abilities, aptitudes, interests and work-life balance" enhance the graduates to attain the adaptability and flexibility attributes for their future readiness for employability (Bridgstock, 2009; Clarke, 2018; Oliver, 2016).

Table 3. Summary of measurement model findings

\begin{tabular}{|c|c|c|c|c|c|c|}
\hline $\begin{array}{l}\text { Constructs (Latent } \\
\text { Variable) }\end{array}$ & $\begin{array}{l}\text { Measureme } \\
\text { nt items } \\
\text { (Indicators) }\end{array}$ & $\begin{array}{c}\text { Converge } \\
\text { nt } \\
\text { Validity } \\
\text { (Loading) }\end{array}$ & $\begin{array}{c}\text { Internal } \\
\text { Consistenc } \\
\text { y } \\
\text { Reliability } \\
\text { CA }\end{array}$ & $\begin{array}{c}\text { Composit } \\
\text { e } \\
\text { Reliabilit } \\
\text { y } \\
\text { CR }\end{array}$ & AVE & $\begin{array}{c}\text { Discrimina } \\
\text { nt } \\
\text { Analysis }\end{array}$ \\
\hline \multirow[t]{7}{*}{$\begin{array}{l}\text { Individual } \\
\text { Attributes }\end{array}$} & IA1 & 0.785 & \multirow[t]{7}{*}{0.901} & \multirow[t]{7}{*}{0.921} & \multirow[t]{7}{*}{$\begin{array}{c}0.59 \\
6\end{array}$} & \multirow[t]{7}{*}{ Yes } \\
\hline & IA 2 & 0.805 & & & & \\
\hline & IA3 & 0.821 & & & & \\
\hline & IA4 & 0.849 & & & & \\
\hline & IA5 & 0.787 & & & & \\
\hline & IA6 & 0.766 & & & & \\
\hline & IA7 & 0.733 & & & & \\
\hline
\end{tabular}


By utilising SEM-PLS 3.0 (Hair Jr et al., 2017), table 3 highlights a brief summary of the results obtained for the measurement model assessment which illustrates that the reliability and validity tests for this study. The findings shows that all the requirements of reliability and validity of the measurement model assessment are met.

\section{Hypothesis Testing}

To conduct the hypotheses testing connected to the structural model of the study, there are several elements are required to be considered. The first element, for a hypothesis to be valid, the value of the path coefficient of 0.1 or higher is required to account for a certain impact within the model (Hair, Ringle, \& Sarstedt, 2011). Secondly, the acceptable t-value and p-value must be greater than 1.96 and less than 0.05 respectively (Ramayah, Cheah, Chuah, Ting, \& Memon, 2018). The hypothesis testing result of the impact of Individual Attributes on the Readiness for Employability is illustrated in table 4.

Table 4. Hypothesis testing results

\begin{tabular}{cccccc}
\hline Path & T & P & $5 \%$ & $95 \%$ & Decision \\
Coefficient & Statistics & Values & BCI & BCI & (p < \\
$\beta$ & & & LL & UL & $0.05)$ \\
\hline
\end{tabular}

$\begin{array}{lllllll}\text { Individual Attributes -> } & 0.254 & 3.245 & 0.001 & 0.122 & 0.384 & \text { Accepted } \\ \text { Readiness for } & & & & & & \\ \text { Employability } & & & & & & \end{array}$

The study findings highlight a significant contribution of the Individual Attributes factor in the Readiness for Employability of the Engineering graduates of the HEIs in Oman. According to the findings, the most influential individual attributes on graduates' readiness for employability are workshop attendance that affect the attainment of the technical skills of the graduates (Jackson, 2015), family motivations, graduates' career orientations that help graduates to identify future career requirements and future career opportunities (Clarke, 2018), and graduates' personal learning targets (Craps et al., 2017). While, class attendance, academic excellence, financial sources, and parents' career position have lesser effects. The findings of this attribute which consist of the individual attributes of personnel's' "values, attitudes, abilities, aptitudes, interests and work-life balance" supported previous studies finding and came to proof its strong influence in enhancing the graduates attaining the adaptability and flexibility attributes for their future readiness for employability (Bridgstock, 2009; Clarke, 2018; Oliver, 2016). Therefore, the Individual attributes play relatively a significant role to encourage the graduates to have adaptable and flexible attitudes to job search and career self-orientation by acquiring the important careerrelated Readiness for employability skills (Okay-Somerville \& Scholarios, 2015).

\section{CONCLUSION AND POLICY RECOMMENDATION}

The findings of the statistical analysis of the study showed the most influential individual attributes on graduates' readiness for employability are workshop attendance that affect the attainment of the technical skills of the graduates, family motivations, and graduates' career orientations that help graduates to identify future career requirements and future career opportunities, and 
graduates' personal learning targets. Also, class attendance, academic excellence, financial sources, and parents' career position showed high important effects as well. Therefore, HEIs are required to pay close attention to workshop equipment and practical activities. This element of individual attributes had scored the highest importance among the individual attributes items which directly affect the attainment of one of the most required engineering skills and competence. Another recommendation for HEIs is to consider involving graduates families as an important aspects for developing their graduates attainment of the required Readiness for Employability skills since family motivations along with graduates' career orientations help graduates to identify future career requirements, future career opportunities, and graduates' personal learning targets (Craps et al., 2017). Also, a third recommendation for HEIs is to promote among its students the importance of class attendance and academic excellence for future career opportunities and sustainment of employability.

Therfore, the findings of this attribute having the personnel's graduates values, attitudes, and abilities had illustrated strong influence in enhancing the graduates attaining the graduates' Readiness for Employability, adaptability, and flexibility for future employability (Bridgstock, 2009; Clarke, 2018; Oliver, 2016). Therefore, the Individual attributes play relatively a significant role to encourage the graduates to have adaptable and flexible attitudes to job search and career self-orientation by acquiring the important career-related Readiness for employability skills (Okay-Somerville \& Scholarios, 2015). Finally, the study's implementations and recommendations could be transferred to the Gulf and Arab or other countries' contexts having similar settings of HE systems and similar issues of skills gap and employability concern of their graduates.

\section{REFERENCES}

Al Hinai, M. R., Bhuiyan, A. B., \& Husin, N. A. (2020a). AN EMPIRICAL REVIEW ON THE GRADUATE ATTRIBUTES AND READINESS FOR EMPLOYABILITY AMONG THE ENGINEERING GRADUATES IN THE HIGHER EDUCATION INSTITUTIONS (HEIs). Indian Journal of Finance and Banking, 4(3), 8-25.

Al Hinai, M. R., Bhuiyan, A. B., \& Husin, N. A. (2020b). THE MODERATING EFFECTS OF GENDER, CAREER, MORAL MINDSET ON THE RELATIONSHIP BETWEEN THE GRADUATE ATTRIBUTES AND READINESS FOR EMPLOYABILITY AMONG ENGINEERING COLLEGES GRADUATES IN OMAN. International Journal of Accounting \& Finance Review, 5(3), 16-30.

Al Hinai, M. R., Bhuiyan, A. B., \& Husin, N. A. (2020c). Theoretical Review on The Graduate Attributes and The Readiness for Employability Among Engineering Graduates in The Higher Education Institutes (HEIs) in Oman. Indian Journal of Finance and Banking, 4(2), 130-139.

AlMunajjed, M., Sabbagh, K., \& Insight, I. C. (2011). Youth in GCC countries: meeting the challenge. Booz \& Company Inc.

Becker, G. S. (1962). Investment in human capital: A theoretical analysis. Journal of political economy, 70(5, Part 2), 9-49. 
Bridgstock, R. (2009). The graduate attributes we've overlooked: Enhancing graduate employability through career management skills. Higher Education Research \& Development, 28(1), 31-44.

Casuat, C. D., \& Festijo, E. D. (2020). Identifying the Most Predictive Attributes Among Employability Signals of Undergraduate Students. Paper presented at the 2020 16th IEEE International Colloquium on Signal Processing \& Its Applications (CSPA).

Clarke, M. (2018). Rethinking graduate employability: The role of capital, individual attributes and context. Studies in Higher Education, 43(11), 1923-1937.

Craps, S., Pinxten, M., Saunders, G., Leandro Cruz, M., Gaughan, K., \& Langie, G. (2017). Professional Roles and Employability of Future Engineers.

Creswell, J. W., \& Creswell, J. D. (2017). Research design: Qualitative, quantitative, and mixed methods approaches: Sage publications.

Dörnyei, Z. (2007). Research methods in applied linguistics: Quantitative, qualitative, and mixed methodologies: Oxford University Press Oxford.

Fugate, M., \& Ashforth, B. E. (2003). Employability: The construct, its dimensions, and applications. Paper presented at the Academy of Management Proceedings.

Fugate, M., Kinicki, A. J., \& Ashforth, B. E. (2004). Employability: A psycho-social construct, its dimensions, and applications. Journal of vocational behavior, 65(1), 14-38.

Gupta, T., Singh, A., \& Kaushik, A. (2018). Placement Predict: A Review of Engineering Graduate Placement Statistics in India. International Journal of Engineering Science, 16381.

Hair, J. F., Ringle, C. M., \& Sarstedt, M. (2011). PLS-SEM: Indeed a silver bullet. Journal of Marketing theory and Practice, 19(2), 139-152.

Hair Jr, J. F., Sarstedt, M., Ringle, C. M., \& Gudergan, S. P. (2017). Advanced issues in partial least squares structural equation modeling: saGe publications.

Heijde, C. M. V. D., \& Van Der Heijden, B. I. (2006). A competence-based and multidimensional operationalization and measurement of employability. Human Resource Management: Published in Cooperation with the School of Business Administration, The University of Michigan and in alliance with the Society of Human Resources Management, 45(3), 449476.

Jackson, D. (2014). Factors influencing job attainment in recent Bachelor graduates: evidence from Australia. Higher Education, 68(1), 135-153.

Jackson, D. (2015). Employability skill development in work-integrated learning: Barriers and best practice. Studies in Higher Education, 40(2), 350-367. 
Leslie, L. L., \& Brinkman, P. T. (1988). The Economic Value of Higher Education. American Council on Education/Macmillan Series on Higher Education: ERIC.

Lim, Y.-M., Lee, T. H., Yap, C. S., \& Ling, C. C. (2016). Employability skills, personal qualities, and early employment problems of entry-level auditors: Perspectives from employers, lecturers, auditors, and students. Journal of Education for Business, 91(4), 185-192.

McMahon, W. W. (2009). Higher learning, greater good: The private and social benefits of higher education: JHU Press.

NCSI. (2015). Statistical Year Book. In: NCSI Muscat, Oman.

Okay-Somerville, B., \& Scholarios, D. (2015). Career Self-Management, Perceived Employability, and Employment Success during University-to-Work Transitions: A Social Cognitive Career Theory Perspective. Zarzadzanie Zasobami Ludzkimi(2015 6 (107) Employability (Zatrudnialność)), 33-60.

Oliver, A. K. (2016). School Capital and Student Engagement: Does School Capital Matter? , University of Redlands,

Pauceanu, A. M., Rabie, N., \& Moustafa, A. (2020). Employability under the Fourth Industrial Revolution. Economics \& Sociology, 13(3), 269-283.

Rahman, M. Z., \& Bhuiyan, A. B. (2019). The Influencing Factors on the Effectiveness of Foundation Training Programs: A Case Study of the Health Cadre Service in Bangladesh. International Journal of Business and Management Future, 3(2), 13-21.

Ramayah, T., Cheah, J., Chuah, F., Ting, H., \& Memon, M. (2018). Partial least squares structural equation modeling (PLS-SEM) using smartPLS 3.0. In An Updated Guide and Practical Guide to Statistical Analysis: Pearson.

Sarfraz, I., Rajendran, D., Hewege, C., \& Mohan, M. D. (2018). An exploration of global employability skills: a systematic research review. International Journal of Work Organisation and Emotion, 9(1), 63-88.

Schultz, T. (1963). The Economics Value of Education . New York and London. Columbia. In: University Press.

Slaughter, S., Taylor, B. J., \& Rosinger, K. O. (2015). A critical reframing of human capital theory in US higher education. Critical approaches to the study of higher education: A practical introduction, 80-102.

Urbano, R. C. (2013). Using secondary datasets to understand persons with developmental disabilities and their families: Academic Press. 
Vanhercke, D., De Cuyper, N., Peeters, E., \& De Witte, H. (2014). Defining perceived employability: a psychological approach. Personnel Review, 43(4), 592-605.

Yang, H., Cheung, C., \& Fang, C. C. (2015). An empirical study of hospitality employability skills: perceptions of entry-level hotel staff in China. Journal of Hospitality \& Tourism Education, 27(4), 161-170.

\section{Copyrights}

Copyright for this article is retained by the author(s), with first publication rights granted to the journal. This is an open-access article distributed under the terms and conditions of the Creative Commons Attribution license (https://creativecommons.org/licenses/by/4.0). 